九州大学学術情報リポジトリ

Kyushu University Institutional Repository

\title{
NOTES ON THE LIOCROBYLA OF JAPAN, WITH DESCRIPTIONS OF TWO NEW SPECIES (Lepidoptera, Gracilari idae)
}

Kuroko, Hiroshi

https://doi.org/10.5109/2337

出版情報: ESAKIA. 1，pp.1-7，1960-01-20. Hikosan biological laboratory，Faculty of Agriculture, Kyushu University バージョン：

権利関係 : 


\title{
NOTES ON THE LIOCROBYLA OF JAPAN, WITH DESCRIPTIONS OF TWO NEW SPECIES*
}

\author{
(Lepidoptera, Gracilariidae)
}

B Y

\author{
Hiroshi Kuroko
}

Hitherto only one species of the genus Liocrobyla, L. paraschista, was described by Meyrick from India. In 1957 Dr. Issiki recorded this species from Japan in the "Icon. Het. Jap. Col. Nat.: 28, t. 4, f. 107 ." Unfortunately, however, Dr. Issiki has confused two other species with Liocrobyla paraschista. By the kind help of Messrs. Tremewan and Bradley, of the British Museum (Natural History), the author was able to know that the true paraschista was a species mining the leaves of Desmodium racemosum DC. and commonly found in Japan. In the present paper the author gives a redescription of the true paraschista and describes two new species of this genus from Japan.

The author wishes to express his sincere gratitude to Prof. K. Yasumatsu, of Kyushu University, and Prof. S. Issiki, of the University of Osaka Prefecture, for their constant encouragement and guidance, to Messrs. W. G. Tremewan and J. D. Bradley, of the British Museum (Natural History) for their kind help in identifying the species.

\section{Genus Liocrobyla Meyrick}

Liocrobyla Meyrick, 1916, Exot. Microlep., 2 : 5.

Type species : Liocrobyla paraschista Meyrick.

Head with crown covered with two large loosely depressed tufts, which extend forward and projecting (canopy shaped) over frons, face with appressed scales; ocelli absent ; tongue developed. Antennae over forewing in length, filiform, simple, basal joint moderate, with pecten. Labial palpi rather long, 2nd joint the longest, drooping and apex loosely curved forward, loosely scaled, terminal

* Contribution Ser. 2, No. 2, Hikosan Biological Laboratory, Kyushu University, Hikosan.

Contribution Ser. 2, No. 24, Entomological Laboratory, Kyushu University, Fukuoka. 
joint pointed. Maxillary palpi consisted of two joints, short, filiform, pointed. Maxillary palpi consisted of two joints, short, filiform, pointed. Middle and posterior tibiae smooth. Forewings narrowly elongate-lanceolate ; lb waved, Ic present, 3 present or absent, 6 and 7 stalked or connate from cell, 7 to costa, 11 from towards base, 12 short. Hindwings $1 / 2$ in width, linear-lanceolate, with some bristles on costa near base, cilia 6; Ic absent, 2 and 3 stalked, 4 absent, 5 and 6 stalked, approximated to 7 about middle. On hind margin of 6 th and 8th segments of male set 2 pairs of long scale tufts. Tergum of 8 th segment of male triangular shaped and projecting backward.

\section{Key to the species}

1. 2nd costal streak of forewing reduced to brownish spot ........ L. paraschista Meyrick (from Desmodium caudatum DC.) 2nd costal streak of forewing developed ............

2. Apex of 2 nd costal streak with a white spot beneath ..

L. paraschista Meyrick (from Desmodium racemosum DC.) Apex of 2 nd costal streak with an indistinct white line beneath .....

3. Tegula grayish fuscous; apex of 1st costal streak with a fine white line beneath $\ldots \ldots \ldots \ldots \ldots \ldots \ldots \ldots$. brachybotrys sp. nov.

Tegula brown or pale brown; apex of 1st costal streak with a white spot

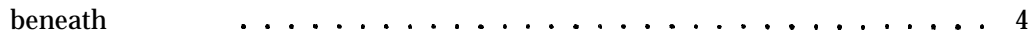

4. White spots on dorsal streak rather angulated, enclosed with black ... . . . . . . L. paraschista Meyrick (from Lespedeza cyrtobotrya Miq.)

- White spots on dorsal streak rounded, not enclosed with black . . . .

Key to the species by male genitalia

1. Valva triangular with a one fingered process; apex of aedoeagus rounded,

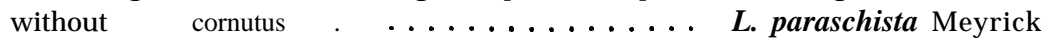
Valva rectangular with a 2 or more fingered process; apex of aedoeagus pointed, with an inversed cornutus .............. 2

2. Valva with a 2 fingered process; cornutus long. .... . L. lobata sp. nov.

- Valva wlth a 4 or 5 fingered process; cornutus short

L. brachybotrys sp. nov.

Liocrobyla paraschista Meyrick

(Figs. 1, 2, 3 \& 6 ; Pl. 1, figs. $9 \& 10$; Pl. 2, figs. $15 \& 16$ )

Liocrobyla paraschista Meyrick, Exot. Microlep. 2:5, 1916; Fletcher, Mem. Dep. Agr. India, Ent. Ser. 6 (6) : 160-161, t. 40, f. 2, t. 41, 1920 ; id., Scient. Monogr. Imp. Counc. Agr. Res. 4: 59, t. 60, 1933; Issiki, Icon. Het. Jap. Col. Nat. : 28, t. 4, f. 107, 1957 (partim).

o. 6-7 mm. Head with crown, whity-brownish, center grayish fuscous; face white, with a few black scales on each side, frontal tuft dark fuscous beneath. Antennae over forewing, filiform, pale grayish fuscous, apex of each joints dark. 

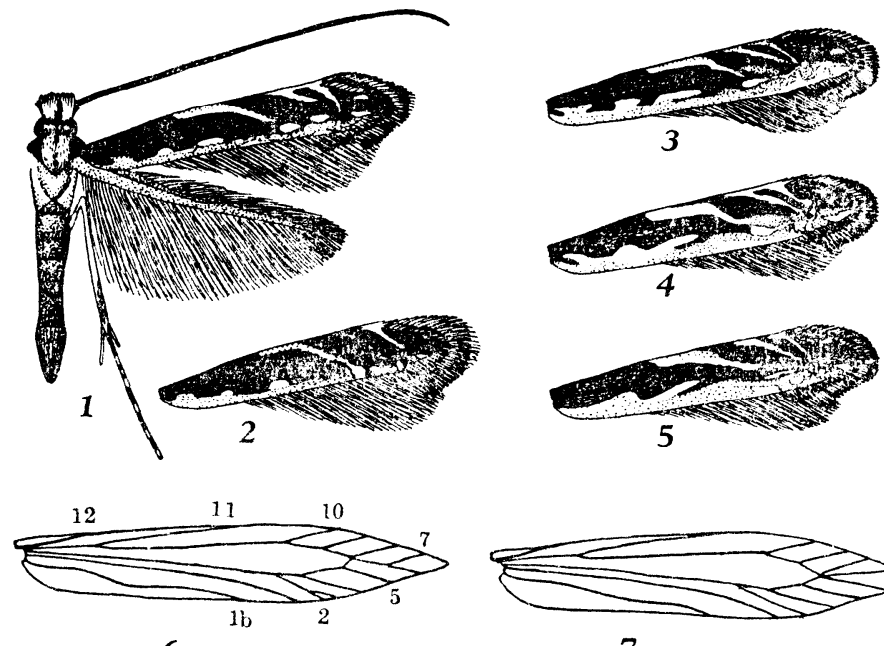

6
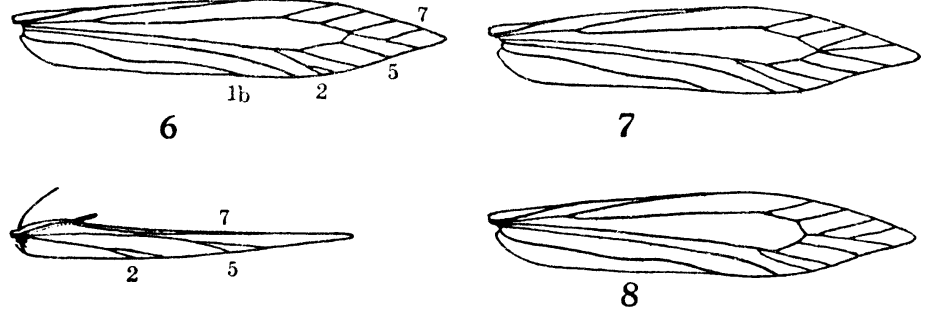

Figs. 1 \& 6. Liocrobyla paraschista Meyrick, bred from Desmodium racemosum DC., showing right half and venation.

Fig. 2. Ditto, bred from Desmodium caudatum DC., right forewing.

Fig. 3. Ditto, bred from Lespedeza cyrtobotrya Miq., right forewing.

Figs. 4 \& 7. Liocrobyla lobata sp. nov., showing right forewing and its venation. Figs. 5 \& 8. Liocrobyla brachybotrys sp. nov., showing right forewing and its venation.

Palpi white, 2nd joint with a black apical band, terminal joints with a black median ring and an apical point.

Thorax whity-brown, tegula grayish fuscous. Abdomen dark bronzy-gray, beneath white. Legs white, with some black oblique bands, tibiae smooth.

Forewings dark bronzy.fuscous; a pale brown dorsal streak from base to near apex, with white spots on $1 / 4$ and $1 / 3$ of dorsal streak; a white streak running from $1 / 3$ of costa slightly along edge and obliqued to $2 / 3$ of disc (1st costal streak), costal edge pale brown, apex of this streak with a white spot beneath; a very oblique white streak from $2 / 3$ of costa to disc (2nd costal streak), apex of this streak with a white spot beneath; an obliquely curved transverse white streak from $3 / 4$ of costa (3rd costal streak), mostly interrupted and tinged with metallicsilvery near disc; white costal and dorsal spots on apical area. Cilia pale grayish fuscous, round apex pale, with two black margined. Hindwings grayish fuscous, cilia pale grayish fuscous. Venation of forewings: 3 present, 6 and 7 stalked. 
Above characters are based on the specimens bred from the larvae mining in the leaves of Desmodium racemosum DC.

The specimens bred from Lespedeza cyrtobotrya Miq. differ from those bred from Desmodium racemosum DC. in the following points, but both forms are the same species.

1. Head and thorax whitish, tegula brown or pale brown.

2. Forewings lighter, white spots on pale brownish dorsal streak larger and enclosed with black.

3. Spot of the apex or 2nd costal streak beneath reduced to a fine line and apical area of forewing brownish.

The specimens bred from Desmodium caudatum DC. are darker than the other ones and the 2nd costal streak is reduced.

It is a very interesting fact that the coloration is variable in accordance with the host plants.

Male genitalia: uncus lobed, weakly sclerotized; valva narrowed apically, outside of apex protruded a fingered process ; saccus widely triangular ; aedoeagus weakly sclerotized, vesica roughened in middle.

Female genitalia : ovipositor elliptical, sclerotized; apophysis posterioris triangular ; apophysis anterioris geniculate; 8th sternum slightly sclerotized and posterior margin of it projecting at the sides; ostium tubular, rather small; ductus bursae membraneus, with sclerotized string ; signum absent.

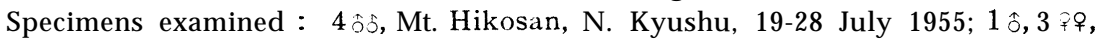
21-26 July 1955; 1 p, 20 Sept. 1956 (H. Kuroko), bred from larvae mining in leaves

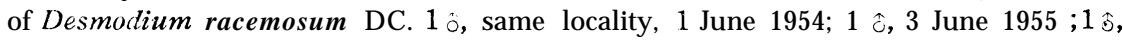
3\%q, 31. July-I Aug. 1956 (H. Kuroko), bred from larvae mining in leaves of

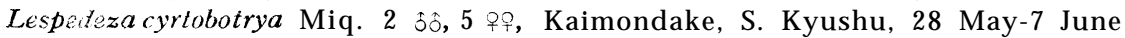
1956 (H. Kuroko), bred from larvae mining in leaves of Desmodium caudatum DC.

Host plants :

Leguminosae: Desmodium racemosum DC. (Jap. name: Nusubitohagi), $D$. Oldhamii Olivier (Jap. natne : Fujikanzô)D. caudatum DC. (Jap. name :Misonaoshi), D. gangeticum DC., Lespedeza cyrtobotrya Miq. (Jap. name : Marubahagi), Cajanus cajan Millsp. (=C. indicus Spreng.), Flemingialineata Roxb., B utea frondosa Rox b.

Distribution : Japan (Hokkaido, Honshu, Kyushu), N. India.

Meyrick (1916) recorded that the present species was bred from the larvae mining in the leaves of Butea frondosa by Maxwell at Kanara, Manchikeri, and from the larvae mining in the leaves of Cajanus indicus by Fletcher at Bengal, Pusa. Fletcher (1920 \& 1933) reported that he bred the species from the larvae mining in the leaves of Cajanus indicus, Desmodium gangeticum and Flemingia lineata at Pusa. Further, he described and figured the mine, larva, cocoon, pupa and adult.

Usually the author got the larvae of this species mining in the leaves of Desmodium racemosum DC. but sometimes from the leaves of D. Oldhamii Oliver 
and Lespedeza cyrtobotrya Miq. on Mt. Hikosan. Further more, the author experienced many cases, in which the larvae were mining in the leaves of $\boldsymbol{D}$. caudatum DC. on Kaimondake, S. Kyushu.

There are three broods in the year. The larvae of the first generation occur from the end of June to the beginning of July, and the adults appear from the end of July to the beginning of August. The larvae of the second generation are met with from the end of August to the middle of September, and produce the adults at the end of September. The larvae of the third generation appear in October, and the larvae hibernate in the cocoons. The hibernated larvae pupate in the next May, and the adults appear between the end of May and the beginning of June.

The egg is deposited on the lower surface of the leaf of the host plant. The sap-feeding larva, as soon as hatched, mines in the lower epidermis of the leaf, mapping out triangularly as its habitation. When the larva changes to the tissue-feeder, the larva feeds in the palisade parenchyma. The mine extends in a digitate blotch under the upper epidermis along the midrib or lateral rib and its coloration is pale green or pale greenish brown with a pale brownish patch in the middle. An oblique pore is made in the lower surface, through which frass of the larva is edjected and the opening of the pore is covered by a small triangular piece consisted of the lower epidermis.

Liocrobyla lobata sp. nov.

(Figs. 4 \& 7; Pl. 1, figs. 11 \& 12; P1. 3, fig. 17)

Liocrobyla parachista Issiki (nec Meyrick, 1916), Icon. Het. Jap. Col. Nat.: 28, t. 4, f. 107, 1957 (partim).

§९. 6-7 mm. This new species closely resembles $L$. paraschista Meyrick, but differs from it in the following characters: head and thorax white, tegula pale brown; coloration of forewings lighter and white mark distinct, white spot of $1 / 3$ on pale brown dorsal streak elongated. However, the final determination must be based upon the difference of the genitalic characters. Venation of forewing: 3 absent, 6-8 connate from cell.

Male genitalia : valva rectangular, from outside of apex protruded two fingered process; saccus narrowly triangular; aedoeagus sclerotized, apex pointed, vesica roughened, with a long inversed cornutus.

Female genitalia : ostium tubular, the largest among those of the three species of Liocrobyla; ostium bursae sclerotized, with a small sclerotized piece.

Distribution : Japan (Hokkaido, Honshu, Kyushu).

Holotype: o, Mt. Hikosan, N. Kyushu, 29 July 1955 (H. Kuroko).

Allotype: ९, the same data as the hototype, 24 July 1956 (H. Kuroko).

Paratype: + , the same data as the hototype, 25 July 1955 (H. Kuroko).

The types are deposited in the collection of the Entomological Laboratory, Kyushu University. All the specimens were bred from the larvae mining in the leaves of Paueraria Zobata Ohwi (Jap. name : Kuzu). The larva mines a 
digitate blotch under the epidermis of the upper surface; its mine is pale green or pale grayish brown.

Liocrobyla brachybotrys sp. nov.

(Figs. 5 \& 8 ; Pl. 1, figs. 13 \& 14; PI. 3, fig. 18)

Liocrobyla paraschista Issiki (nec Meyrick, 1916), Icon. Het. Jap. Col. Nat. : 28, t. 4, f. 107, 1957 (partim).

\$3. 6-7 $\mathrm{mm}$. The present new species is very closely related to the former two species. Head and thorax white, tegula grayish fuscous. Forewings slightly darker than those of Zobata, white spot of $1 / 3$ on pale brown dorsal streak elongated, white spot of the apex of 1st costal streak lined beneath. Without the aid of genitalic characters it is very difficult to distinguish the species from the other two ones. Venation of forewing: 3 absent, 6 and 7 stalked, 8 out of the stalk.

Male genitalia : valva almost rectangular, process of outside of apex 4 or 5; saccus narrowly triangular ; aedoeagus sclerotized, apex pointed, vesica roughened, with a short inversed cornutus.

Female genitalia : very similar to that of Zobata but apophysis posterioris more elongated and ostium shorter than that of Zobata.

Distribution : Japan (Honshu, Kyushu).

Holotype: §, Mt. Hikosan, N. Kyushu, 2 Aug. 1956 (H. Kuroko).

Allotype: $\%$, the same data as the holotype, 4 Aug. 1956 (H. Kuroko).

Paratypes : 1\%, the same data as the holotype, 4 July 1955; 1 ㅇ, 6 June 1956 ;

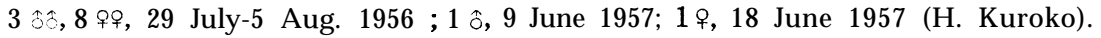

The types are deposited in the collection of the Entomological Laboratory, Kyushu University. All the specimens were bred from the larvae mining in the leaves of Wisteria brachybotrys Sieb. et Zucc. (Jap. name: Yamafuji). The larva mines an elongate or digitate blotch along the midrib; its mine is pale brown, bordered by pale green. 


\section{Explanation of Plates}

Plate 1

Fig. 9. Liocrobyla paraschista Meyrick, male genitalia.

Fig. 10. Ditto, female genitalia.

Fig. 11. Liocrobyla Zobata sp. nov., male genitalia.

Fig. 12. Ditto, female genitalia.

Fig. 13. Liocrobyla brachybotrys sp. nov., male genitalia.

Fig. 14. Ditto, female genitalia.

\section{Plate 2}

Fig. 15. Leaf of Desmodium racemosum DC. mined by the larvae of Liocrobyla paraschista Meyrick.

Fig. 16. Leaves of Lespedeza cyrtobotrya Miq. mined by the larvae of Liocrobyla paraschista Meyrick.

\section{Plate 3}

Fig. 17. Leaf of Pueraria Zobata Ohwi mined by the larvae of Liocrobyla lobata sp. nov.

Fig. 18. Leaves of Wisteria brachybotrys Sieb. et Zucc. mined by the larvae of Liocrobyla brachybotrys sp. nov. 


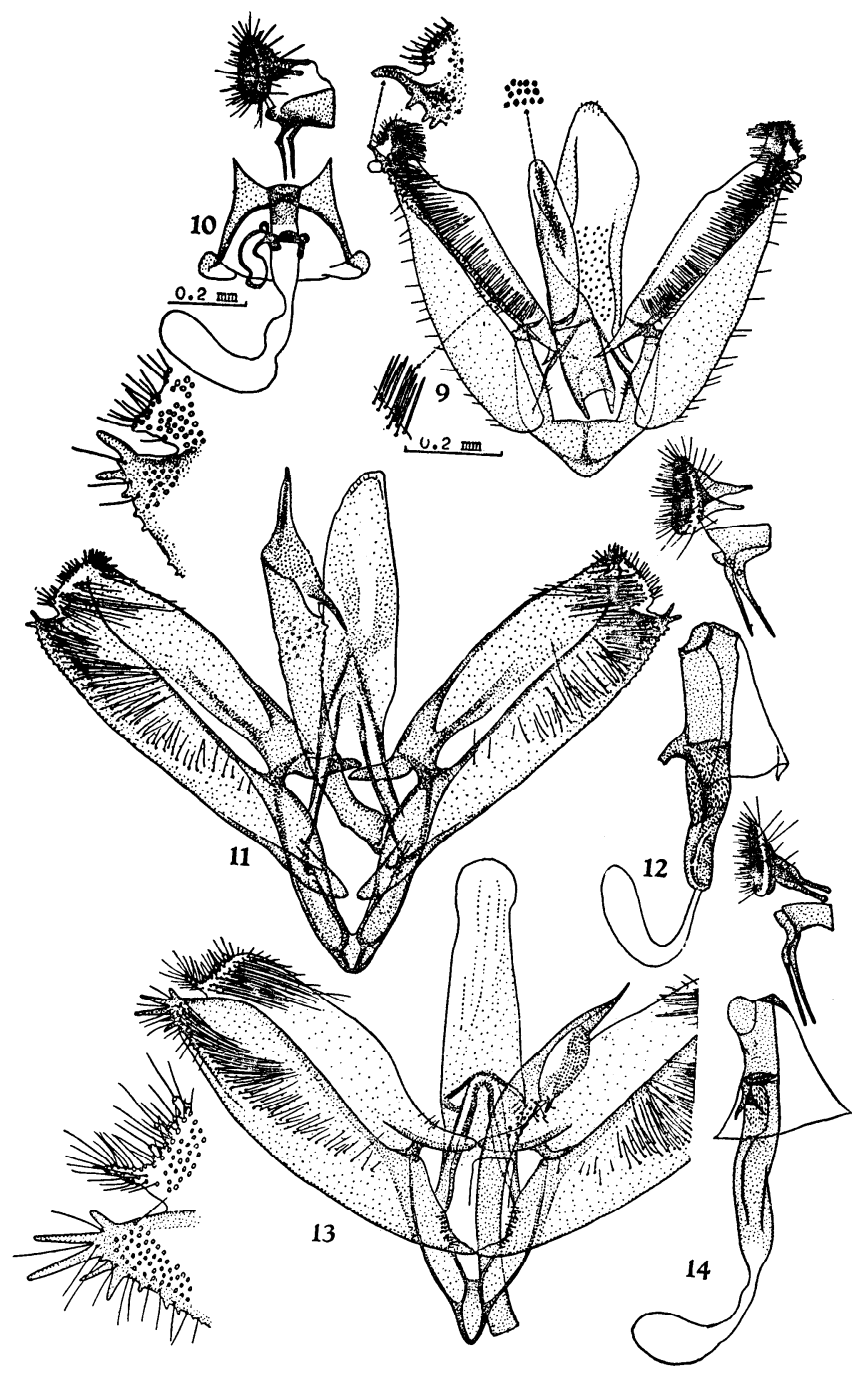




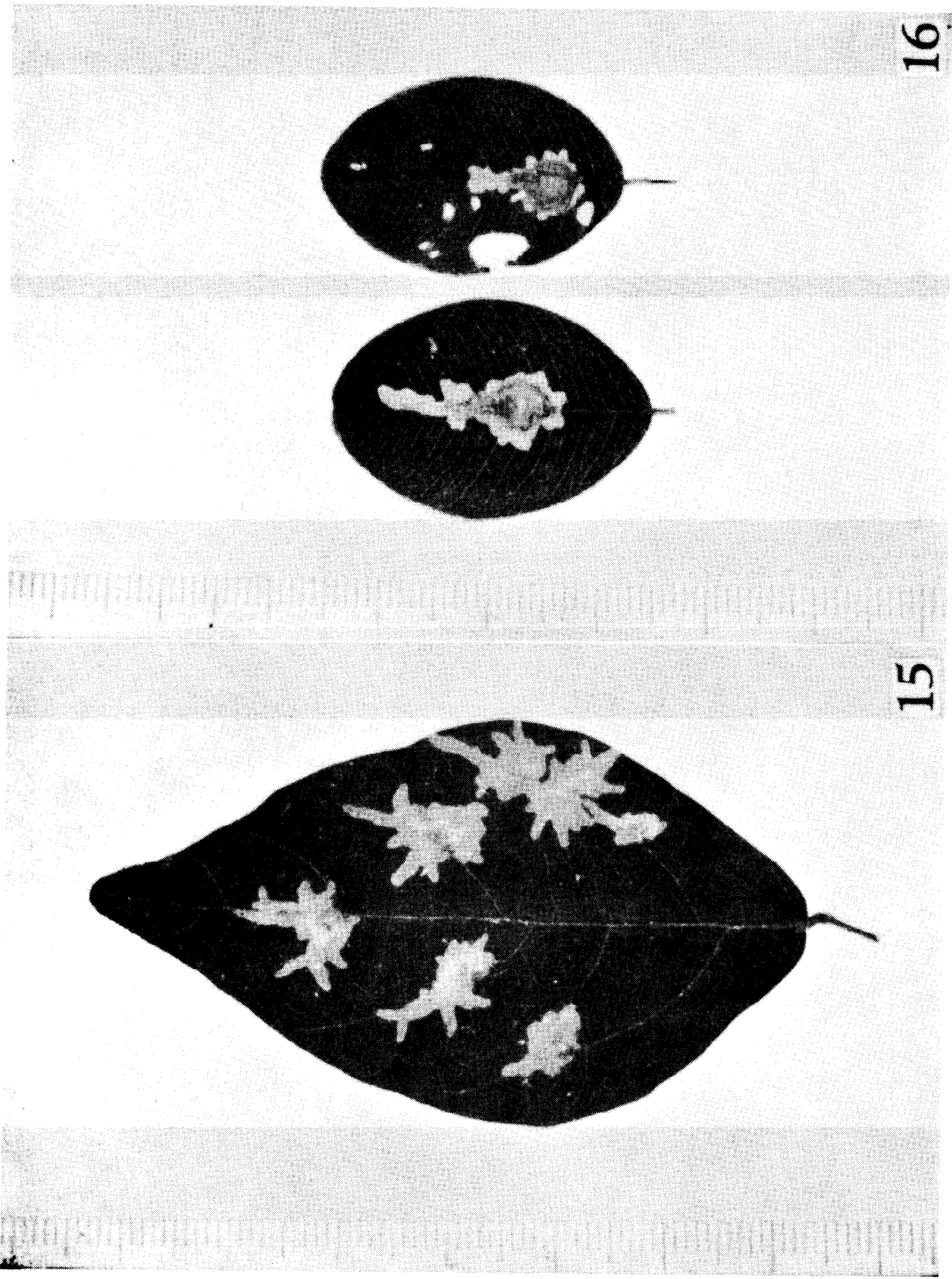




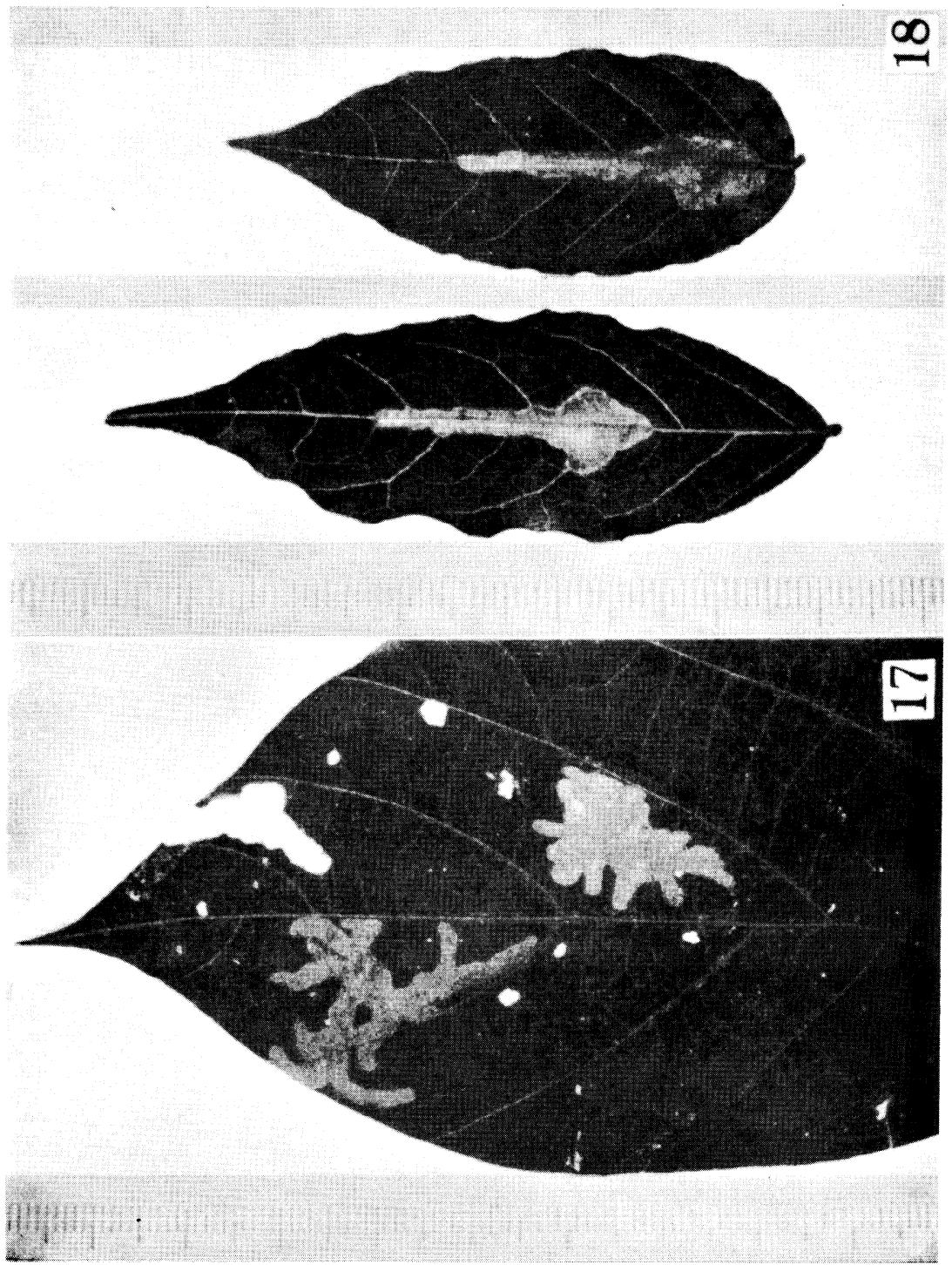

